\title{
Wildlife numbers on excellent and good condition Chihuahuan Desert rangelands: An observation
}

\author{
GRETCHEN SMITH, JERRY L. HOLECHEK, AND MANUAL CARDENAS
}

\begin{abstract}
Authors are graduate research assistant and professor, Department of Animal and Range Sciences; and professor, Department of Experimental Statistics, New Mexico State University, Las Cruces, N.M. 88003.
\end{abstract}

\begin{abstract}
Information is lacking on the influence of range condition on wildlife populations in the Chihuahuan Desert. Wildlife observations were made along transects on ranges in excellent and good ecological condition in south-central New Mexico (86\% and $72 \%$ of climax vegetation remaining, respectively). Black grama (Bouteloua eriopoda Torr.) dominated the excellent condition range while the good condition range had a mixture of grasses, forbs, and shrubs. Plant species diversity was greater on the good compared to excellent condition range. Total mammal sightings $/ \mathrm{km}^{2}$ during the study period were higher $(P<0.05)$ on the good compared to excellent condition range (October 1991 through October 1992). More species of wildlife were seen on the good compared to excellent condition range. Sightings of important game species (scaled quail, mourning doves, pronghorn, desert cottontails) were higher on the good compared to excellent condition range. Lack of diversity in vegetation composition and structure appear to explain the lower wildlife sightings on the excellent condition range. Results from this study indicate that Chihuahuan Desert ranges in good ecological condition (51-75\% of the climax vegetation) will better meet the needs of most wildlife species than ranges in climax or near climax range condition. Research shows grazing intensities that remove on average about 1/3 of current year's growth of key forage species (black grama) are effective in developing and maintaining range in good ecological condition in the Chihuahuan Desert.
\end{abstract}

Key Words: wildlife, pronghorn, quail, arid lands, cattle

Various wildlife species on both public and private rangelands in the Chihuahuan Desert are becoming increasingly important as sources of recreation and income (Cutler 1990). Before any wildlife species or group of species can be properly managed they must have adequate habitat. Therefore the range managers must understand how range condition class relates to the needs of different wildlife species. It has been argued that Chihuahuan Desert rangelands in good ecological condition can provide better wildlife habitat than those in lower or higher ecological condition because good condition rangelands support more diverse mixtures of grasses, forbs, and shrubs compared to mostly grasses on

This research was supported by the New Mexico Agr. Exp. Sta., Las Cruces, New Mexico and was part of project 1-5-27417.

Manuscript accepted 20 Dec. 1995. excellent condition and mostly shrubs on fair or poor condition rangelands (Holechek 1991). The objective of our study was to explore the validity of this argument via comparison of wildlife numbers on Chihuahuan Desert rangelands in excellent and good ecological condition in south-central New Mexico.

\section{Materials and Methods}

\section{Study Area Description}

Two study sites with similar soils, terrain, and precipitation were selected based on their ecological condition classification. A study site in excellent condition was located on the Bureau of Land Management, Goodsight Allotment $24 \mathrm{~km}$ northeast of Deming, N.M. The condition classification was assessed using Dyksterhuis (1949) quantitative climax guidelines and data collected by Smith (1993). The excellent condition range supports about $86 \%$ of the climax vegetation. The good condition study site is located on the New Mexico State University College Ranch $37 \mathrm{~km}$ north of Las Cruces, N. M., and supports $72 \%$ of the climax vegetation. We recognize that replication would have improved the validity of our study. However excellent condition range is rare in the Chihuahuan Desert. There was lack of opportunity to study wildlife numbers on replicated sites in excellent and good condition.

Soils at both sites consist mostly of sandy loams classified as paleorthids, haplargids or calciorthids. The excellent condition study site has a sandy clay loam component. Both study sites have an undulating restrictive caliche layer. However the caliche layer on the good condition site occurs at slightly greater depth than on the excellent condition site (Smith 1993). We recognize that some of the difference in vegetation on the 2 sites could be due to soils. However we believe the soils are similar enough that most of the difference is due to grazing management. Past records show that prior to the 1950's drought the good condition pasture was dominated by black grama (Bouteloua eriopoda Torr.) and considered to be in excellent condition (Holechek et al. 1994). The topography at both sites is relatively flat with all slopes under $5 \%$. The excellent condition study site is 860 ha in size and the good condition study site involves 1,280 ha.

Annual precipitation at both locations is typical of the 
Chihuahuan Desert. The precipitation is bimodal with a peak in the summer and another peak in the winter. The summer peak in late August provides $20-25 \%$ and the winter peak in January provides $13-15 \%$ of the annual precipitation (Pieper and Herbel 1982). The mean annual precipitation for the excellent and good condition study sites is near $250 \mathrm{~mm}$. Temperature in June reaches a mean maximum of $36^{\circ} \mathrm{C}$ and during January drops to a mean maximum of $13^{\circ} \mathrm{C}$ (Pieper and Herbel 1982).

The climax vegetation for both study areas is considered to be black grama (Bouteloua eriopoda Torr.) grassland with a scattering of soaptree yucca (Yucca elata Engelm.) (Buffington and Herbel 1965). The present vegetation on the excellent condition range is dominated by black grama (Table 1). Scattered yucca plants are present, and creosotebush (Larrea tridenta Lar.) occupies limited area on the periphery.

Primary grass species on the good condition range include black grama, mesa dropseed (Sporobolus flexuosus Thurb. Rybd.) and spike dropseed (Sporobolus contractus A. Hitch.) (Table 1). Honey mesquite (Prosopis glandulosa Torr.) dominates the overstory and has increased over the past 50 years (Pieper and Herbel 1982). In degraded areas near watering points, broom snakeweed (Gutierrezia sarothrae Pursh.) is dominant. Important forbs include leatherweed croton (Croton pottsii Lam.), nightshades (Solanum spp.), and globemallow (Sphaeralcea spp.). More detailed descriptions of the study areas are provided by Smith (1993).

\section{Graxing Histories}

The excellent condition study area was contained within 1 pasture. Historically, this pasture was conservatively stocked (30-35\% use of key forages). The grazing strategy has incorporated periodic rest during the growing season (1 May-1 October 1). During the period of study, however, the pasture was continuously grazed. The annual stocking rate averaged $20 \mathrm{ha} / \mathrm{animal}$ unit. Fall standing crop of perennial grasses on the excellent range in 1991 was nearly double that on the good condition range
(Smith 1993). Both ranges showed only light grazing use during the study based on our empirical observations.

The good condition study area contained 4 pastures. One was continuously grazed while the others were grazed in a seasonal suitability strategy. For the past 25 years these pastures have been conservatively stocked with utilization of key forage species (black grama and mesa dropseed) averaging about 30\%. McNeely (1983) and Beck and Kiesling (1991) found that the seasonal suitability pastures had similar vegetation to the continuous grazed pasture. Therefore, transects were placed across the 2 grazing strategies without concern of confounding. The annual stocking rate averaged $48 \mathrm{ha} /$ animal unit (Beck and Kiesling 1991).

\section{Vegetation Analyses}

Four transects $6.4 \mathrm{~km}$ in length were established on the good condition study site along the road that borders the west side of the pastures. Two transects $3.2 \mathrm{~km}$ in length and $41.6 \mathrm{~km}$ in length were established on the excellent condition range. Foliar cover data $(\%)$ data were collected along these transects in spring and fall of 1992. The line-intercept method (Canfield 1941) as modified by Holechek and Stephenson (1983) was used to determine percent cover. A meter stick was used instead of a line. A total of 80 sampling points were taken for each study area during 1 sampling period. Spacing between sampling points varied with the length of the transect. Sampling was at $320 \mathrm{~m}$ intervals on 6.4 $\mathrm{km}$ transects, and at $160 \mathrm{~m}$ intervals on $3.2 \mathrm{~km}$ transects. The meter stick was placed perpendicular to the transect and the intercept of the plants were measured (Bonham 1989). Plants were identified according to Allred (1988). Standing crop $\left(\mathrm{g} / \mathrm{m}^{2}\right)$ measurements were also collected in fall 1991, spring 1992, and fall 1992, and are reported by Smith (1993).

\section{Wildlife Evaluation}

Transects used for evaluation of wildlife numbers were the same as those used for vegetation evaluations. Wildlife species occurring within a $100-\mathrm{m}$ strip (approximately $50 \mathrm{~m}$ on each side

Table 1. Vegetation foliar cover ( $(\%)$ on the excellent (EC) and good condition (GC) study areas in southcentral New Mexico.

\begin{tabular}{|c|c|c|c|c|c|c|}
\hline \multirow[b]{2}{*}{ Species } & \multicolumn{2}{|c|}{ April 1992} & \multicolumn{2}{|c|}{ October 1992} & \multicolumn{2}{|c|}{ Mean } \\
\hline & $\overline{\mathrm{EC}}$ & GC & $\overline{\mathbf{E C}}$ & $\mathrm{GC}$ & $\overline{\mathrm{EC}}$ & $\overline{G C}$ \\
\hline \multicolumn{6}{|l|}{ Grasses } & --- \\
\hline Bouteloua eriopoda & $17.37^{\mathrm{a}}$ & $8.75^{b}$ & $23.41^{\mathrm{a}}$ & $12.04^{\mathrm{b}}$ & $20.40^{\mathrm{a}}$ & $10.39^{b}$ \\
\hline Sporobolus spp. & 0.00 & 6.44 & 0.00 & 8.66 & 0.00 & 7.55 \\
\hline Aristida spp. & 1.30 & 2.30 & 2.42 & 5.09 & 1.86 & 3.69 \\
\hline Muhlenbergia spp. & 11.78 & 0.00 & 10.04 & 0.00 & 10.91 & 0.00 \\
\hline Erianeuron pulchellum & 1.28 & 0.75 & 1.83 & 1.30 & 1.55 & 1.03 \\
\hline Other grasses & 2.08 & 0.01 & 0.81 & 0.36 & 1.45 & 0.18 \\
\hline Total grasses & $33.83^{a}$ & $18.23^{b}$ & $38.51^{\mathrm{a}}$ & $27.45^{b}$ & $36.17^{a}$ & $22.84^{b}$ \\
\hline \multicolumn{7}{|l|}{ Forbs } \\
\hline Sphaeralcea spp. & 0.75 & 0.31 & 0.00 & 0.06 & 0.38 & 0.19 \\
\hline Croton pottsii & 0.03 & 0.06 & 0.77 & 0.04 & 0.40 & 0.05 \\
\hline Other forbs & 0.55 & 1.60 & 0.85 & 0.63 & 0.70 & 1.11 \\
\hline Total forbs & 1.33 & 1.97 & 1.62 & 0.73 & 1.48 & 1.35 \\
\hline \multicolumn{7}{|l|}{ Shrubs } \\
\hline Gutierrezia sarothrae & 0.00 & 5.18 & 0.00 & 6.75 & 0.00 & 5.97 \\
\hline Prosopis glandulosa & 0.67 & 7.13 & 0.00 & 6.54 & 0.33 & 6.84 \\
\hline Yucca elata & 0.00 & 2.29 & 0.50 & 1.22 & 0.25 & 1.75 \\
\hline Other shrubs & 0.00 & 1.61 & 0.00 & 0.00 & 0.00 & 0.80 \\
\hline Total shrubs & 0.67 & 16.21 & 0.50 & 14.51 & $0.58^{a}$ & $15.36^{b}$ \\
\hline Total vegetation cover & 35.83 & 36.41 & $40.63^{a}$ & $42.69^{a}$ & $38.23^{a}$ & $39.55^{a}$ \\
\hline
\end{tabular}

a,b Different superseripts within dates and rows reflect differences $(\mathrm{P}<0.05)$ using standard T-test. 
Table 2. Wildlife sightings (sightings $/ \mathrm{km}^{2}$ ) for 5 seasons on excellent (EC) and good (GC) condition study areas in the Chihuahuan desert of New Mexico.

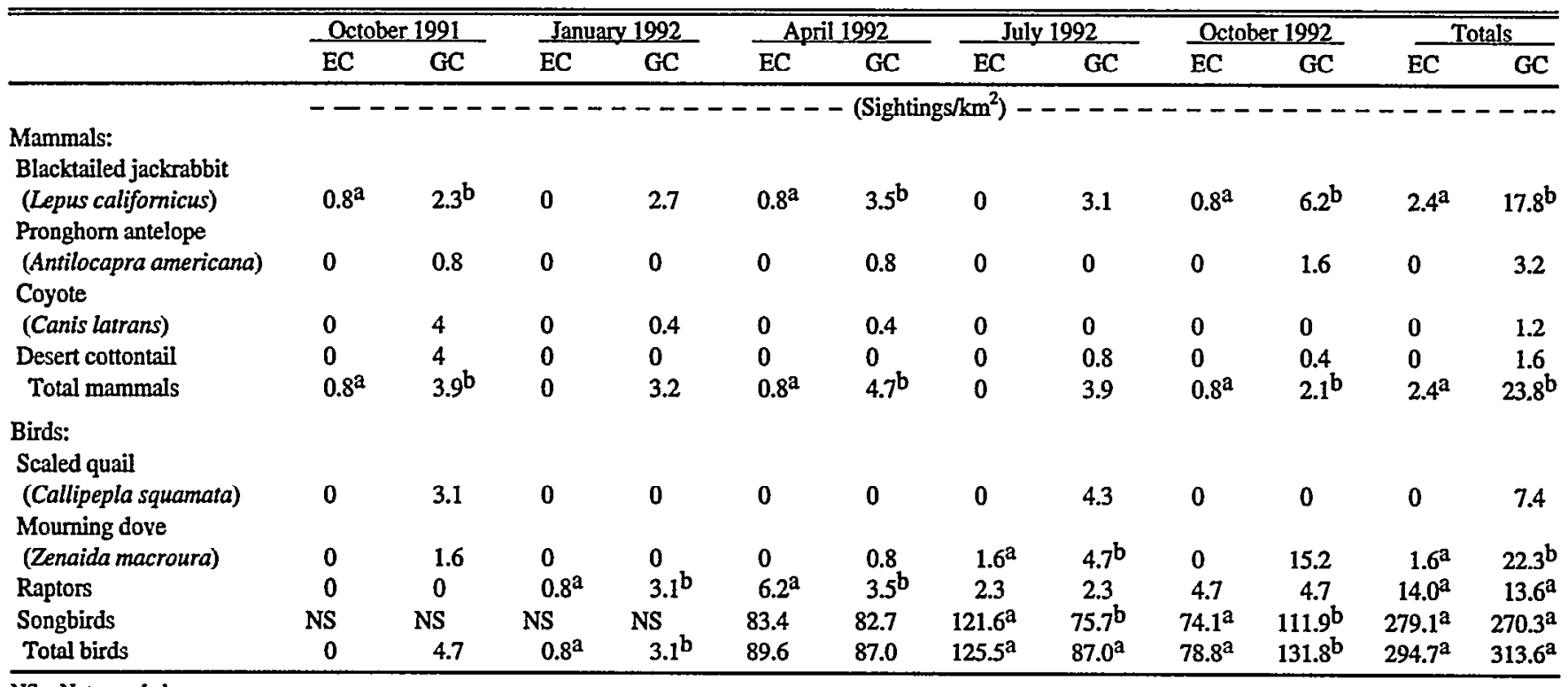

NS = Not sampled.

a,b Different superscripts within dates and rows reflect differences $(P<0.05)$ using standard T-test.

of the transect line) were enumerated. The separation of transects by $500 \mathrm{~m}$ avoided double enumeration of mammals. Wildlife species enumerated included: pronghorn (Antilocapra americana Ord), coyotes (Canis latrans Merriam), blacktailed jackrabbits (Lepus californicus J. A. Allen), desert cottontails (Sylvilagus anduboni Mearns), scaled quail (Callipepla squamata Vigors), mourning doves (Zenaida macroura Limaeus), and several songbird and raptor species. The species and number of individuals within a sighting were recorded. The transects at each study site were walked at the same time each morning. This allowed removal of any variation in the data due to animal movements. Early moming was used because it coincides with maximum animal activity. The sampling dates were; October 1991, January 1992, April 1992, July 1992, and October 1992. Data were converted to wildlife sightings per $1 \mathrm{~km}^{2}$ (100 hours) for statistical evaluation.

\section{Statistical Analyses}

Standard t-tests using transects as replicates were used to compare vegetation cover composition and wildlife sightings $/ \mathrm{km}^{2}$ between pastures within seasons (Steel and Torrie 1980), except where empty cells occurred. The Shannon-Weiner diversity index (Barbour et al. 1987) was used to evaluate vegetation and wildlife diversity on the excellent and good condition ranges.

\section{Results and Discussion}

Total mammal sightings were higher $(\mathrm{P}<0.05)$ on good than excellent condition range (Table 2). We attribute this difference to the higher shrub component on the good condition range (Table 1). Wood (1969) reported higher small mammal populations on mid-seral compared with near climax Chihuahuan Desert range.
More blacktailed jackrabbits were observed $(\mathrm{P}<0.05)$ on good than on excellent condition range. This difference is probably explained by the lack of shrubs on the excellent condition range. Shrubs provide black-tailed jackrabbits with both food and cover (Daniel et al. 1993). Across 4 consecutive seasons Daniel et al. (1993) found open grassland areas had the lowest jackrabbit densities while areas dominated by shrubs were intermediate and areas with an interspersion of grasses, forbs, and shrubs had the highest jackrabbit densities.

Pronghom were not observed on the excellent condition range although they were seen in adjacent pastures. We attribute this to lack of shrubs. Pronghorn diets are composed mainly of forbs and browse (Beale and Smith 1970, Howard et al. 1990). The mean total forb cover did not differ ( $P>0.05$ ) between the 2 ranges but shrub cover differed substantially (Table 1).

Trevino (1978) found that pronghorn in Chihuahua, Mexico used honey mesquite and other shrubs for shade. Buechner (1950) provided evidence that shrubs in the Trans-Pecos Region of Texas protected the pronghorn from cold north winds, blizzards, and severe heat. Although the Chihuahuan Desert seldom receives blizzards, strong wind and drastic drops in temperature do occur in winter and summers are quite hot. Shrubs are probably important for pronghorn in the New Mexico Chihuahuan Desert as windbreaks and sources of shade and seasonally important sources of dietary protein.

Our results are consistent with those of Clemente (1993), which showed that pronghorn used Chihuahuan Desert ranges in good ecological condition more than ranges in lower or higher successional stages.

The good condition range had more different bird species sightings than the excellent condition range. The primary bird category on both ranges was songbirds. Songbird sightings showed no consistent difference between good and excellent condition rangelands (Table 2). Davis et al. (1974) studied bird populations 
on areas with varying degrees of shrub densities in the Chihuahuan Desert. They found bird diversity was greater on areas supporting a shrub component compared to open grasslands.

Scaled quail were encountered only on the good condition range (Table 2). However, we have observed scaled quail on pastures adjacent to the excellent condition range in lower ecological condition. The lack of scaled quail sightings on the excellent condition range is probably a function of unsuitable plant species for food and cover. Saiwana (1990) found areas with mixtures of grasses, forbs, and shrubs had higher scaled quail populations in the Chihuahuan Desert than grasslands or shrublands. He suggested that the best habitat for scaled quail is provided by upland sandy areas with $45-55 \%$ remaining climax vegetation moderately grazed by cattle.

Shrubs and half shrubs such as honey mesquite and broom snakeweed are important to scaled quail for both food and cover (Davis et al. 1974). These plants are considered to be increasers and are absent or occur at low levels on ranges in climax condition. Campbell et al. (1973) speculated that vegetation changes caused by moderate cattle grazing can improve habitat conditions for scaled quail. Our results and those of Bock et al. (1984) support this speculation.

Mourning dove sightings were higher $(P<0.05)$ on the good compared to excellent condition range. Our data indicate open grasslands with few forbs and shrubs are not ideal habitat for mourning doves. In Arizona, Bock et al. (1984) found mourning dove populations were higher on grazed than ungrazed areas. In south Texas heavily grazed areas had higher mourning dove populations than those that were moderately grazed (Baker and Guthery 1990). This was explained by higher food availability on the heavily grazed areas.

Redroot pigweed (Amaranthus pubescens [Uline and Bray] RYBD.) and leatherweed croton (Croton pottsii Lam.) are in important mourning dove foods in southern New Mexico (Davis and Anderson 1973). Leatherweed croton, also called doveweed, was more available on the good compared to excellent condition range (Table 1). Redroot pigweed is most prevalent around watering points that have been heavily grazed by livestock (Fusco 1993). Mourning doves make considerable use of honey mesquite for nesting and roosting (Soutiere and Bolen 1976). Research by Saiwana (1990) indicates that rangeland in fair ecological condition best meets the needs of mourning doves in the Chihuahuan Desert.

Based on the Shannon-Weiner index, wildlife diversity was greater on the good compared to excellent condition range (2.53 versus 1.19 , respectively). This index is based on total number of species observed and proportion of each species within the total. Vegetational diversity was also greater on the good compared to excellent condition range (3.38 versus 2.72 , respectively). Our data suggest that wildlife population diversity is positively correlated with vegetation diversity. However individual species of wildlife such as Cassin's sparrow (Aimophila cassinii Woodhouse) may use only those rangelands at or near the climax (Bock et al. 1984). Generally large tracts of rangeland in good overall condition will include areas in both higher and lower successional stages, and such mosaics can provide suitable habitat for nearly all the wildlife species that naturally occur in the area.

\section{Experimental Limitations}

We acknowledge that lack of replication is a limitation in our study. However opportunities to replicate this type of study on comparable sites large enough for meaningful data are restricted. The problem is that few large areas of excellent condition rangeland remain in the Chihuahuan Desert.

Our technique involved enumerations along belts $100 \mathrm{~m}$ by $1.6-$ $6.4 \mathrm{~km}$. We also acknowledge that this sampling procedure has limitations for conversion of wildlife sightings into density and biomass estimates. The problem for us was that the high labor and time requirements to walk the relatively long transects needed in this type of study puts constraints on the detail that can be put into distance measurements required for the Burham et al. (1980) technique when several wildlife species are sampled at once.

Although brush cover was generally below shoulder height on the good condition pastures, it did to some extent impair visibility on the good compared to excellent condition study site. This could have caused us to underestimate some wildlife species on the good condition study site. In spite of these limitations, we consider the findings from our study to be valid.

\section{Management Implications}

Concern over wildlife has been a justification to remove livestock grazing from public lands. Many environmentalists believe livestock removal will permit public rangelands to return to the climax or excellent ecological condition. Although our study has some limitations, it does indicate that climax conditions provide less than ideal habitat for many wildlife species in the Chihuahuan Desert, and lower seral stages with $55-75 \%$ remaining climax vegetation are suitable for maximizing wildlife species diversity. Research indicates a moderate stocking rate that removes $30-35 \%$ of key perennial grasses will permit recovery of many poor or fair condition Chihuahuan Desert rangelands to good condition (Paulsen and Ares 1962, Holechek 1991, 1992). Good condition Chihuahuan Desert rangelands provides high quality wildlife habitat, a moderate return from livestock production and maintains soil stability based on the present and other studies (Paulsen and Ares 1962, Holechek 1991, 1992). If the goal is maximum monetary returns from livestock production, excellent condition range is best (Holechek 1996).

\section{Literature Cited}

Allred, K. 1988. A floral guide to the flora of the Jornada plain. New Mexico Agr. Exp. Sta. Bull. 739.

Baker, D.L. and F.S. Guthery. 1990. Effects of continuous grazing on habitat and density of ground-foraging birds in south Texas. J. Range Manage. 43:2-6.

Barbour, M.G., J.H. Burk, and W.D. Pitts. 1987. Terrestrial Plant Ecology. Benjamin/Cummings Publishing Company, Inc. Menlo Park, Calif.

Beale, S.L. and A.D. Smith. 1970. Forage use, water consumption, and productivity of pronghom antelope in western Utah. J. Range Manage. 34:570-582. 
Beck, R.F. and H.E. Kiesling. 1991. Improving range and cattle production on semidesert rangeland. Livestock Research Briefs and Cattle Growers Short Course. N. Mex. Agr. Exp. Sta., Coop. Ext. Ser. and New Mexico Cattle Growers Assn., Las Cruces, N.M.

Bock, C.E., J.H. Bock, W.R. Kenney, and J.M. Hawthorne. 1984. Response of birds, rodents, and vegetation to livestock exclosure in a semidesert grassland site. J. Range Manage. 37:239-243.

Bonham, C.D. 1989. Measurements for Terrestrial Vegetation. John Wiley and Sons. N. Y.

Buechner, H.K. 1950. Life history of the pronghorn antelope in TransPecos Texas. Amer. Midland Nat. 43:257-354.

Buffington, L.C. and C.H. Herbel. 1965. Vegetation changes on semidesert grassland range from 1958-1963. Ecol. Monogr. 35:139-164.

Burnham, K.P., D.R. Anderson, and J.L. Laake. 1980. Estimation of density from the line transect sampling of biological populations. Wildl. Monogr. 72:1-202.

Campbell, H., D.K. Martin, P.E. Ferkovich, and B.K. Harris. 1973. Effects of hunting and some other environmental factors on scaled quail in New Mexico. Wildl. Monogr. 34.

Canfield, R.H. 1941. Application of the line intercept method in sampling range vegetation. J. Forest. 39:388-394.

Clemente, F. 1993. Influence of range condition, cattle, and watering hole distribution on a pronghorn population in southcentral New Mexico. Ph.D. Thesis, New Mexico State Univ., Las Cruces, N.M..

Cutler, M.R. 1990. Appreciative use of wildlife - the recreational choice of 3 out of 4 Americans. pp. 25-32. In: Proc. from the conference on: income opportunities for the private landowner through management of natural resources and recreational access. Eds. W. Grafton, A. Ferrise, D. Colyer, D. Smith, and J. Miller, West Virginia University Extension Service, Morgantown, W.V.

Daniel, A, J. Holechek, R. Valdez, A. Tembo, L. Salwana, M. Fusco, and M. Cardenas. 1993. Jackrabbit densities on fair and good condition Chihuahuan desert range. J. Range Manage. 46:524-528.

Davis, C.A. and W.M. Anderson. 1973. Seasonal food use by mourning doves in the Mesilla Valley, southcentral New Mexico. New Mexico Agr. Exp. Sta. Bull. 612.

Davis, C.A., P.B. Saywer, J.P. Griffing, and B.D. Borden. 1974. Bird populations in shrub-grassland area, Southeastern New Mexico. New Mexico Agr. Exp. Sta. Bull. 619.

Dyksterhuis, E.J. 1949. Condition and management of rangeland based on quantitative ecology. J. Range Manage. 2:104-115.

Fusco, M. 1993. Grazing influences on watering point vegetation in the Chihuahuan desert. M.S. Thesis. New Mexico State Univ., Las Cruces, N.M.

Holechek, J.L. 1991. Chihuahuan desert rangeland, livestock grazing, and sustainability. Rangelands 13:115-120.

Holechek, J.L. 1992. Financial aspects of cattle production in the Chihuahuan desert. Rangelands 14:145-149.

Holechek, J.L. 1996. Financial returns and range condition on southern New Mexico ranches. Rangelands 18:52-56.

Holechek, J.L. and T. Stephenson. 1983. Comparison of big sagebrush in northcentral New Mexico under moderately grazed and grazing excluded conditions. J. Range Manage. 36:455-456.

Holechek, J.L., A. Tembo, A. Daniel, M.J. Fusco, and M. Cardenas. 1994. Long-term grazing influences on Chihuahuan Desert rangeland. Southw. Nat. 39:342-349.

Howard, V. W., J. L. Holechek, R. D. Pieper, K. Green-Hammond, M. Cardenas, and S. L. Beasom. 1990. Habitat requirements for pronghorn on rangeland impacted by livestock and net wire in east central New Mexico. New Mexico Agr. Exp. Sta. Bull. 750.

McNeely, R.P. 1983. Influence of mesquite on vegetational changes under 2 grazing strategies in southem New Mexico. M.S. Thesis. New Mexico State Univ., Las Cruces, N.M.

Paulsen, H.A., Jr. and F.N. Ares. 1962. Grazing values and management of black grama and tobosa grasslands and associated shrub ranges of the Southwest. USDA Forest. Serv. Tech. Bull. 1270. Washington, D.C.

Pieper, R.D. and C.H. Herbel. 1982. Herbage dynamics and primary productivity of a desert grassland ecosystem. New Mexico Agr. Exp. Sta. Bull. 695.
Saiwana, L. 1990. Range condition effects on scaled quail in southcentral New Mexico. Ph.D. Thesis. New Mexico State Univ., Las Cruces, N.M.

Smith, G.T. 1993. Influence of excellent and good condition Chihuahuan Desert range on vegetation, cattle diets, and wildlife populations. M.S. Thesis. New Mexico State Univ., Las Cruces, N.M.

Soutiere, E.C. and E.G. Bolen. 1976. Mourning dove nesting on tobosa grass-mesquite rangeland sprayed with herbicides and burned. $J$. Range Manage. 29:226-231.

Steel, R.G. and J.H. Torrie. 1980. Principles and procedures of statistics. McGraw-Hill Book Co., N.Y.

Trevino, J.C. 1978. Number and distribution of pronghorn antelope in Chihuahuan, Mexico. M.S. Thesis. New Mexico State Univ., Las Cruces, N.M.

Wood, J.E. 1969. Rodent populations and their impact on desert rangelands. New Mexico Agr. Exp. Sta. Bull. 555. 